\title{
Regionalism versus Multilateralism
}

\author{
Jagdish Bhagwati
}

\section{INTRODUCTION}

$\widetilde{\mathfrak{d}}$

HE question of 'regionalism,' defined broadly as preferential trade agreements among a subset of nations, is a longstanding one. As with all great issues, economists have long been divided on the wisdom of such arrangements. So have policymakers.

The question of customs unions (CUs) and free trade areas (FTAs), both permitted under GATT Article XXIV, has long been a major topic of theoretical research. The focus, however, since Jacob Viner's (1950) classic treatment of it, distinguishing between trade diversion and trade creation, has been on showing that CUs and FTAs were not necessarily welfare-improving, either for member countries or for world welfare. That is, the case for preferential trade arrangements was different from the case for free trade for all. The latter, enshrined in Adam Smith and Ricardo, and rigorously proven later by Samuelson (1939), Kemp (1972), and Grandmont and McFadden (1972), is a first-best case. The former, by contrast, reflects second-best considerations and was argued by Lipsey and Lancaster (1956-57), Lipsey (1957), Meade (1956), Johnson (1958a and 1958b) and others.'

The recent revival of regionalism, which I describe as the Second Regionalism in contrast and because it is a sequel to the First Regionalism of the $1960 \mathrm{~s}$, raises anew these old questions about trade diversion. But the

JAGDISH BHAGWATI is Arthur Lehman Professor of Economics and Professor of Political Science at Columbia University. This is an abbreviated version of the paper presented to a World Bank Conference on April $2 \& 3,1992$ in Washington DC. It reflects the author's personal views and bears no relationship to his position as Economic Policy Adviser to the Director-General, GATT. Thanks are due to Robert Baldwin, James Benedict, Richard Blackhurst, Christopher Bliss, Don Davis, Sunil Gulati, Douglas Irwin, John McMillan, Arvind Panagariya, T. N. Srinivasan and John Whalley for helpful conversations and suggestions. The full version will be published in a volume to be edited by James de Melo and Arvind Panagariya and published by Cambridge University Press in 1993.

The Vinerian approach to customs union theory has been carried forward by others recently, chiefly by Berglas (1979) and Corden (1976). In addition, three alternative theoretical approaches can be distinguished: by Kemp and Wan (1976); by Cooper and Massell (1965a and 1965b), Johnson (1965) and Bhagwati (1968); and by Brecher and Bhagwati (1981). All four approaches are distinguished and discussed in the graduate textbook by Bhagwati and Srinivasan (1983, Chapter 27) and in Bhagwati (1991a). Each is touched upon later in the text. 
historically-changed situation which has resurrected regionalism, the context in which it must be analyzed, has raised several new issues.

In this paper, I address these manifold questions, dividing the analysis into a discussion of:

- Article XXIV of the GATT which sanctions CUs and FTAs (Section 2);

- the First Regionalism, briefly reviewing the factors that led to it and the reasons why, in the end, it failed (Section 3);

- the Second Regionalism, the reasons for its revival and its differential prospects (Section 4);

- the key issues that this renewed Regionalism raises, distinguishing among two main questions (Section 5);

- the first, relating to the static impact-effect of regional trade blocs (Section 6); and

- the second, concerning the dynamic time-path that regionalism offers, in itself and vis-a-vis multilateralism when the objective is to reach (nondiscriminatory) free trade for all, so that one asks whether 'multilateralism is the best way to get to multilateralism', distinguishing therefore between 'process-multilateralism' and 'outcome-multilateralism' (Section 7).

\section{ARTICLE XXIV AT THE GATT: RATIONALE}

The principle of nondiscrimination is central to the final conception of the GATT, signed on October 30, 1947 by representatives from 23 countries in Geneva. Article I embodies the strong support for nondiscrimination, requiring (unconditional) MFN for all GATT members.

Aside from 'grandfathering' provisions, the only significant exception to MFN is made in Article XXIV which permits CUs and FTAs and therefore sanctions preferential trade barrier reductions among a subset of GATT members as long as they go all the way to elimination. ${ }^{2}$

It is an intriguing question as to why Article XXIV was accepted; and it is a question that also has significance for some of the issues raised by the Second Regionalism. When you think about it, it is a bit odd that an exception to MFN should be allowed as long as it is total (going all the way to 100 per cent) rather than partial (say, 20 per cent preference for one's favoured friends). In fact the

\footnotetext{
${ }^{2}$ Two points should be noted. First, there is a difference between intention and reality: as argued below, the Article XXIV - sanctioned FTAs and CUs have never gone 'all the way.' Second, GATT's MFN is universal only for its members, so it falls short of total universalism. But the important point to remember is that the GATT is open to membership to all who meet the criteria for admission and has generally been inclusive rather than exclusive.
} 
post-Vinerian theory of preferential trade areas suggests that 100 per cent preferences are less likely to increase welfare than partial preferences. ${ }^{3}$

The rationale for Article XXIV's inclusion in the GATT therefore must be explained in other ways. Perhaps, there was an inchoate, if strong, feeling that integration with 100 per cent preferences somehow was special and consonant with the objective on multilateralism. Thus, Kenneth Dam (1970, pp. 274-75) quotes the prominent US official Clair Wilcox as follows:

A Custom union (with $100 \%$ preferences) creates a wider trading area, removes obstacles to competition, makes possible a more economic allocation of resources and thus operates to increase production and raise planes of living. A preferential system (less than 100\%) on the other hand, retains internal barriers, obstructs economy in production, and restrains the growth of income and demand. . . . A customs union is conducive to the expansion of trade on a basis of multilateralism and nondiscrimination; a preferential system is not.

Wilcox's statement was little more than assertion, however. But the rationale for inclusion of Article XXIV in the GATT appears to have been threefold, as follows.

- Full integration on trade, that is, going all the way down to freedom of trade flows among any subset of GATT members, would have to be allowed since it created an important element of single-nation characteristics (such as virtual freedom of trade and factor movements) among these nations, and implied that the resulting quasi-national status following from such integration in trade legitimated the exception to MFN obligation toward other GATT members.

- The fact that the exception would be permitted only for the extremely difficult case where all trade barriers would need to come down, seemed to preclude the possibility that all kinds of preferential arrangements would break out, returning the world to the fragmented, discriminatory bilateralism-infested situation of the 1930s.

- One could also think of Article XXIV as permitting a supplemental, practical route to the universal free trade that GATT favoured as the ultimate goal, with the general negotiations during the many Rounds leading to a dismantling of trade barriers on a GATT-wide basis while deeper integration would be achieved simultaneously within those areas

\footnotetext{
${ }^{3}$ Of course, this theory developed after the incorporation of Article XXIV into the GATT. So, its inconsistency with Article XXIV, on its own terms, is only an amusing observation perhaps. Note, however, that James Meade was a main actor in both. The argument is developed in two alternative ways in Lipsey (1960, p. 507) and in Johnson (1967, p. 203).
} 
where politics permitted faster movement to free trade under a strategy of full and time-bound commitment. This is an argument that is now at centre stage: is regionalism truly a building, rather than a stumbling, bloc towards multilateral free trade for all; in other words, will it fragment, or integrate, the world economy?

The clear determination of 100 per cent preferences as compatible with multilateralism and nondiscrimination, and the equally firm view that anything less was not, meant that when Article XXIV was drafted, its principal objective was to close all possible loopholes by which it could degenerate into a justification for preferential arrangements of less than 100 per cent. Paragraphs 4 through 10 of Article XXIV were written precisely for this purpose. But, as is now commonly conceded, their inherent ambiguity and the political pressures for approval of substantial regional groupings of preferences of less than 100 per cent have combined to frustrate the full import of the original desire to sanction only 100 per cent preferences.

Dam's (1970, p. 290) overall judgement is perhaps too harsh but it is certainly in the ballpark:

The record is not comforting. . . . Perhaps only one of the more than one dozen regional arrangements that have come before the GATT complied fully with Article XXIV criteria. That was the recent United Kingdom/Ireland FreeTrade Area, and even in that case certain doubts were expressed before the working party. In some cases, the regional arrangements were very wide off the mark. The European Coal and Steel Community, covering only two major product lines, could not even qualify for the special regional-arrangement waiver of Article XXIV:10 but required a general waiver under Article XXV:5. The New Zealand/Australia Free-Trade Agreement, although not purportedly an example of 'functional integration,' provided for the liberalization of an even smaller percentage of intermember trade. A strong tendency has also been manifested for interim agreements to provide for an even longer transitional period and to contain increasingly fewer detailed commitments for eventual completion of the customs union or freetrade area.

\section{THE 'FIRST REGIONALISM': FAILURE IN THE 1960s}

In any event, one can correctly assert (based on the acceptance of Article XXIV into the GATT) that regionalism, in the shape of (100 per cent) customs unions and free trade areas, was not generally considered, by the architects of the GATT or by the United States, which was the chief proponent of multilateralism and nondiscrimination, as antithetical to the GATT and to these principles. 
1. Nonetheless, the United States, long suspicious of discriminatory trade arrangements, restrained itself from resorting to Article XXIV. The formation of the European Community in 1958 marked a partial watershed. The United States put its shoulder to the wheel and saw the Common Market through, negotiating around the different hoops of Article XXIV, emasculating the Article somewhat so as to seek GATT approval of an imperfect union (especially in regard to discriminatory preferences for the eighteen ex-colonies in Africa which the Europeans insisted on retaining, and which required a waiver of GATT rules), all in the cause of what it saw as a politically beneficial union of the original six nations that formed the Community. But despite the enthusiasm of many to follow the EC with a North Atlantic Free Trade Area (NAFTA), and even a Pacific Free Trade Area (PAFTA), centred on the United States, nothing came of it: The United States remained indifferent to such notions. ${ }^{4}$

2. There was an outbreak of FTA proposals in the developing countries as well. While stimulated by the European examples, they were motivated by the altogether different economic rationale formulated by Cooper and Massell (1965a and 1965b), Johnson (1965) and Bhagwati (1968). This was that, given any targeted level of import-substituting industrialisation, the developing countries, with their small markets, could reduce the cost of this industrialisation by exploiting economies of scale through preferential opening of markets with one another. ${ }^{5}$ By the end of the $1960 \mathrm{~s}$, however, the attempts at forming regional free trade areas and customs unions along these lines had also collapsed. The problem was that, rather than use trade liberalisation and hence prices to guide industry allocation, the developing countries attempting such unions sought to allocate industries by bureaucratic negotiation and tie trade to such allocations, putting the cart before the horse and killing the forward motion.

Thus, while the world was indeed filled in the 1960s with proposals for NAFTA, PAFTA, LAFTA (the Latin American Free Trade Area), and ever more, until one could be forgiven for imagining that a veritable chemical revolution had broken out, regionalism had virtually died by the end of the decade, except for the original European Community and EFTA.

\footnotetext{
${ }^{4}$ Japan probed, in fact, the possibility of going into such an arrangement with the United States as one of its partners in the 1960 s but to no avail.

'The question of 'multilateralism' versus 'regionalism' surfaced at a different level even within this preferential trade liberalisation among the developing countries. Thus, in the early 1960s, we were discussing whether the Cooper-Massell-Johnson-Bhagwati argument should not be considered on a G-77-wide basis rather than for much smaller groups of developing countries. This was the main issue before a 1962 UNCTAD Expert Group in New York, of which I was a member, which met over three weeks to draft the recommendation that preferential trade liberalisation among the developing countries be 'multilateral,' i.e. G-77-wide, rather than narrowly-focused. Unfortunately, the preferential arrangements that were contemplated took the latter, narrower focus.
} 


\section{THE 'SECOND REGIONALISM': REVIVAL IN THE 1980s}

But regionalism (i.e. preferential trade liberalisation) is now back. Those who do not know the history of the First Regionalism are doomed to extrapolate from the current political ferment in favour of FTAs and CUs and assume uncritically that regionalism is here to stay. Those who know the history may make the reverse mistake of thinking that regionalism will fail again.

I believe that careful analysis of the causes of the resurrection of regionalism suggests that regionalism is likely to endure this time. The main driving force for regionalism today is the conversion of the United States, hitherto an abstaining party, to Article XXIV. Beginning with the FTA with Israel (a reflection of the special relationship between the two nations and hence of little general value), the FTA with Canada marked a distinct change. Now, the NAFTA is being negotiated with Mexico, and the Enterprise for the Americas Initiative envisages more FTAs with the nations of South America, with Chile at the head of the line.

The conversion of the United States is of major significance. As the key defender of multilateralism through the postwar years, its decision now to travel the regional route (in the geographical and the preferential senses simultaneously) tilts the balance of forces away at the margin from multilateralism to regionalism.

This shift has taken place in the context of an anti-multilateralist ethos that has reflected alternative but nonetheless eventually reinforcing views:

- The 'Memorial Drive' school ${ }^{6}$ holds that the GATT is dead (Thurow: Davos) or the GATT should be killed (Dornbusch et al., 1989). ${ }^{7}$ Regionalism then is presented in effect as an alternative to multilateralism. This school, aptly named in view of its funereal approach to multilateralism, has influence in Democratic circles and plays to the prejudices that one finds in Congressional circles that mistakenly identify multilateralism with America's postwar altruism and regionalism (with its connotation of

\footnotetext{
${ }^{6}$ The MIT economics Department is at 50 Memorial Drive in Cambridge, Massachusetts. I obviously exclude Charles Kindleberger, Paul Samuelson and the diaspora, including myself! If the views expressed with Dornbusch in a recent Eastman Kodak publication (1989) are a guide, Krugman may at times hold one of the positions described above. This pamphlet makes somewhat odd and untenable statements about what the GATT does and does not do. Cf. Michael Finger's (1989) rather blunt analysis of these assertions in The World Economy and my own complaints about the confusions following from loose writing on trade policy issues, and the resulting prostitution of an important debate, in Bhagwati (1991b) The American Enterprise (Nov./Dec. 1991). Whether the Memorial Drive school has by now shifted under fire its anti-multilateral stance and joined the more common view that regionalism is a useful supplement, not an alternative, to multilateralism is anyone's guess, given the conflicting reports one hears of its many oral pronouncements on the lecture circuit from its peripetatic members. But if it truly has abandoned its early vitriolic anti-GATT positions, I would be delighted in its demise.

${ }^{7}$ I rely upon oral presentation at the 1988 annual meeting of the American Enterprise Institute in Washington DC.
} 
'exploiting for ourselves our own markets') with the presumed current necessity to 'look after one's interests finally.'

- An alternative view is that regionalism is a useful supplement, not an alternative, to multilateralism. 'We are only walking on two legs' is the popular argument. That we may wind up walking on all fours is ignored.

- It is also often asserted that regionalism will not merely supplement multilateralism. It will also accelerate the multilateral process: the threat of going (unilateral and) regional will produce multilateral agreements that may otherwise be held up. (However, this may be an optimistic view since threats that have to be repeatedly implemented, as has been the case with US regionalism, are not efficient threats; and they change external perceptions about what US trade policy priorities are, quite regardless of what the US asserts to be its true intentions. In fact, the taking of two roads simultaneously can affect adversely the travel down one, as I argue at length below.)

- The panic over the continuing payments deficit has also fed demands for 'quick' results on trade (although the two issues are broadly delinkable: payment surpluses and deficits are macro-economic phenomena that are not influenced in any predictable way by trade policy changes whose impact on the difference between domestic savings and investment, if any, can come in different ways that can go in opposed directions). Associated with this has been impatience with the pace of the multilateral trade-negotiating process and the non sequitur (examined below) that regionalism necessarily works faster.

- In addition, Europe 1992 and impending integration of Eastern Europe into the European Community have reinforced, the way the formation of the Common Market did with many three decades ago, those in North America who feel that a countervailing bloc must be formed there as well. Indeed, the fear that European investments would be diverted to Eastern Europe, once it is integrated with the European Community, was cited by President Salinas of Mexico as a factor decisively pushing him toward the Mexico-US FTA: this would, he felt, enable Mexico to get the needed investment from America and Japan.

- There are strong noneconomic, political and cultural factors also driving Mexico toward a free trade area with its northern neighbour. Just as the Turks since Ataturk have tried to seek a European rather than an Arab identity, the Mexicans clearly seek now an American future rather than one with their southern neighbours. The Hispanic (economic) destiny that many in America fear from illegal immigration and integration with Mexico has its flip side in the American (economic) destiny that Mexico's reforming elite, trained in the top universities in the United States, hopes for. 
- The offer in June 1990 by President Bush to get more nations from South America to join the United States in a free trade area, as part of a general package of economic initiatives to assist these nations, is reflective of the compulsions that the debt crisis there imposes on American policy to respond in a regional framework to ensure that this crisis remains manageable and does not engulf the United States, whose banks are principally endangered by it.

- Then again, the response of South American nations to the prospect of FTAs with NAFTA, and in some cases with one another first and then joining up with NAFTA, has been enthusiastic. This time around, the prospects are better than in the 1960s. Quite simply, there is now a marked shift in economic thinking towards trade liberalisation and market forces. The macroeconomic crisis of the $1980 \mathrm{~s}$ has fed the movement to microeconomic reforms, much as it is doing currently in India. The changed economic and political attitudes are comforting to those of us who went into the trenches to fight these battles as early as the 1960s. It is also amusing to see those who dismissed our arguments as 'reactionary' or 'ideological' then, now embracing these ideas and policies and the leaders who are implementing them, with no apologies to us and with a facade of independently-obtained wisdom. But frankly, it is good to have them finally on the right side; and it is good to have been in the right.

- Finally, the conjunction of the two dramatic events, Europe 1992 and the US-Canada Free Trade Arrangement, even though fortuitous and prompted by different motivations and historical circumstances, certainly has created a sense elsewhere that regionalism is the order of the day and others must follow suit. In the Far East, for instance, there has been a sense that a Japancentred regional bloc may be necessary in a bloc-infested world, and Malaysia has actively sought a Japan-centred Asian bloc to rival and confront the US-led Americas' bloc.

\section{REGIONALISM VERSUS MULTILATERALISM: KEY QUESTIONS}

In the light of the above one suspects therefore that the Second Regionalism will endure: it shows many signs of strength and few points of vulnerability. But, if so, those of us who see virtue in a rule-based, open and multilateral trading system must ask searching questions as to its compatibility with such discriminatory trading arrangements. In particular, two major questions must be answered:

- Is the immediate impact-effect of such preferential trade blocs, whether CUs or FTAs, to reduce rather than increase world welfare? 
- Regardless of the immediate impact-effect, will regionalism lead to nondiscriminatory multilateral free trade for all, through continued expansion of the regional blocs until universal free trade is reached, or will it fragment the world economy? And will, in any event, such a dynamic time-path show that regionalism will get us closer to the goal of multilateral free trade for all than multilateralism as the process of trade negotiation will?

I shall now treat each of these two important, and distinct (if at times analytically interrelated), questions in turn.

\section{THE STATIC IMPACT-EFFECT QUESTION}

The question of the static impact-effect of preferential trade arrangements such as FTAs and CUs is, quite simply, the question raised by Viner (1950): would not such discriminatory arrangements be trade-diverting rather than tradecreating? ${ }^{8}$

It is important to raise this question because, as Viner taught us, FTAs and CUs are two-faced: they liberalise trade (among members), but they protect (against outsiders). The important issue therefore is: which aspect of an FTA or $\mathrm{CU}$ is dominant? Or, to put it in the economist's language: is a particular FTA or $\mathrm{CU}$ trade-diverting (that is, taking trade away from efficient outside suppliers and giving it to inefficient member countries) or trade-creating (that is, generating trade from one more-efficient member at the expense of another lessefficient member)?

Sadly, one may scan the op.ed. articles, the editorials, and the Congressional testimony when the renewal of fast-track authority for the extension of NAFTA to Mexico was being debated last year, looking for references to trade diversion - and find scarcely any. Astonishingly, it was not just the politicians and lawyers for Mexico's lobby who equated the FTA with (nondiscriminatory) free trade; reputed economists did so too.

What can we say about this issue? In particular, what can we propose to ensure that, if CUs and FTAs are to flourish, they do not become tradediversionary? Article XXIV's injunction not to raise the CU's or FTA's average external tariff can be interpreted as a precaution against trade diversion and harm to outside GATT members, though (as argued below) this is not a satisfactory way to do it.

\footnotetext{
${ }^{8}$ Defined in Vinerian fashion, a trade-diverting FTA can still improve a member country's welfare but will generally harm outside countries. The focus below is on the impact on others, as is presumably the intention also of Article XXIV's injunction not to raise the average external tariff.
} 
In essence, there are three approaches to containing the fallout of trade diversion from CUs and FTAs.

\section{a. Converting Preferential CUs and FTAs into (Geographically) Regional \\ Blocs:}

It is occasionally argued that we should encourage geographically-proximate countries to form CUs and FTAs, discouraging geographically distant countries from doing so since the latter would be more likely to be trade-diverting. This is a misguided prescription in my view, for several reasons.

To see this, it must be first appreciated that it rests on a syllogism. The first premise is that a CU or FTA is more likely to create trade and thus raise welfare, given a country's volume of international trade, the higher is the proportion of trade with the country's CU or FTA partners and the lower is this proportion with the nonmember countries. The second premise is that countries sharing borders, or closer geographically to one another, have higher proportions of trade with one another than countries which are further apart.

The first premise is, of course, well known to trade economists from the early post-Vinerian theory, as developed by Lipsey (1958). But Lipsey's argument focuses on the relative sizes of imports from each source vis-a-vis expenditure on domestic goods as the key and decisive factor in determining the size of losses and gains from the preferential cuts in trade barriers.

While the likelihood argument is valid within the Lipsey model, it must be noted that it is only that. Thus, for specific CUs and FTAs, the actual welfare effects will depend, not merely on the trade and expenditure shares $a$ la Lipsey but also on the substitution at the margin between commodities. Thus, for instance, the substitution between nonmember goods and domestic goods may be very high, so that the costs of discrimination would tend to be high as well, ceteris paribus. In short, it is important to guess at substitution elasticities among goods as well as trade shares, with and between members and nonmembers of CUs and FTAs, to arrive at a better picture of the likely effects of specific CUs and FTAs that may be proposed.

As for the second premise, I have problems with that too, as a policy guideline. If I had access to captive research assistance and funds, I could examine whether, for all conceivable combinations of countries and distances among them, and for several different time periods, the premise is valid. As I do not, I must rely on casual empiricism and a priori arguments. Compare for instance the trade through the 1960s between India and Pakistan with that between India and the UK or the USSR. The former trade has been smaller than the latter. Borders can breed hostility and undermine trade, just as alliances among distant countries with shared causes can promote trade (Gowa and Mansfield, 1991). The flag follows trade; and trade equally follows the flag 
which, at least in the 19th century European expansion, was not directly across from the European nations' borders. Again, even if the premise is statistically valid for any set of observations, it may be a result of trade diversion itself: proximity may have led to preferential grant of concessions such as OAP and GSP at the expense of countries elsewhere.

In short, prescriptions to confine CUs and FTAs only to geographically proximate countries are not defensible because both premises have problems: the former is, at best, a likelihood proposition that should not be applied to specific situations where the welfare impact depends critically on other variables as well, whereas the latter does not have a firm empirical or conceptual basis.

But possibly the most damaging criticism that one can make of such a prescription is that it concentrates, at best, on the static impact-effect question and ignores the more important dynamic time-path question. By prescribing that we must rule out 'distant'-country unions, as between the US and Israel or Chile, we would make the CUs and FTAs more exclusive and less open to new members, undercutting the objective of moving speedily towards the shared objective of (nondiscriminatory) multilateral free trade for all. That would be tragic indeed.

\section{b. Designing Disciplines to Minimise Trade Diversion}

A different, and my preferred, approach is, not to pretend to find rules of thumb to exclude CUs and FTAs 'likely' to be trade-diversionary, but rather to examine the different ways in which trade diversion could arise and then to establish disciplines that would minimise its incidence.

Article XXIV. In a sense, Article XXIV (paragraph 5) seeks to do this by requiring that $\mathrm{CUs}$, which must have a common external tariff, should ensure that this common tariff "shall not on the whole by higher or more restrictive than the general incidence of the duties and regulations of commerce applicable . . . prior to the formation of such a union.' For FTAs, the rule is that the 'duties and other regulations of commerce' are not to be 'higher or more restrictive' than those previously in effect.

Evidently, when tariffs change, as in CUs, and some increase and others fall, the scope for skullduggery arises again, since Article XXIV leaves the matter wholly ambiguous. As Dam (1970, p. 217) has noted:

these ambiguities plagued the review by the CONTRACTING PARTIES to the EEC Treaty of Rome - The Six, having used an arithmetic average, refused to discuss the best method of calculation, because in their view paragraph 5 did not require any special method.

Besides, it is evident to trade economists that maintaining external tariffs unchanged is, in any event, not the same as eliminating trade diversion. What 
can be said is that, the lower the external barriers, the less is the scope for diverting efficient foreign supplies to member countries. Thus, a desirable discipline to impose on CUs and FTAs would be to require, for Article XXIV sanction, that one price to be paid must be the simultaneous reduction of the external tariff (implicit and explicit), pro rata to the progressive elimination of internal trade barriers.

Possible ways of ensuring this may be indirect disciplines. One way would be to modify Article XXIV to rule out FTAs with diverse tariffs by members ${ }^{9}$ and to permit only CUs with common external tariffs. With most tariffs bound, this would ensure that for the most part a substantial downward shift in tariffs would be a consequence - that, say, Argentina or Brazil would be lowering her trade barriers, not that the United States would be raising hers. Since regionalism is probably going to be a matter of low-trade-barrier hubs such as the United States and Japan joining with their respective regional spokes, this insistence on CUs could perhaps produce excellent results.

An alternative, surer way would be to insist on CUs but also to write into Article XXIV the requirement that the lowest tariff of any union member on an item before the union must be part of the common external tariff of the union.

Articles VI and XIX: AD and VERs. But none of this is enough today. For, the trade economists who work in a sustained way on the problems of the world trading system are aware that protection today takes the form of unfair capture of fair trade mechanisms such as Anti-Dumping (AD) actions and of Voluntary Export Restraints (VERs). Thus, countries today have access to selective and elastic instruments of protection. ${ }^{10}$ Given this reality, even the modification of Article XXIV, to ensure that the external (implicit and explicit) tariff barriers come down as a price for CUs to be allowed under GATT rules, will leave open a big, gaping hole that would be tantamount to an open invitation to trade diversion by these preferential arrangements. In fact, trade creation can degenerate rapidly into trade diversion, when AD actions and VERs are freely used. Let me explain.

Imagine that the United States begins to eliminate (by outcompeting) an inefficient Mexican industry once the FTA goes into effect. Even though the most-efficient producer is Taiwan, if the next-efficient United States outcompetes the least-efficient Mexico, that would be desirable trade creation (though the best course would be free trade so that Taiwan would take more of the Mexican market instead).

But what do you suppose the Mexicans would be likely to do? They would probably start anti-dumping actions against Taiwan, which would lead to

\footnotetext{
${ }^{9}$ In any event, by encouraging rules of origin because the trade-barrier walls everywhere are not equally high, FTAs encourage in tum the bureaucratic-cum-industry capture of the essentially arbitrary 'local content' rules for protectionist purposes.

10 VERs are evidently selective by countries. AD actions are selective down to the level of the firm, as Brian Hindley has noted.
} 
reduced imports from Taiwan as the imports from the United States increased, leaving the Mexican production relatively unaffected. Trade diversion from Taiwan to the United States would have occurred. Similarly, the effect of Mexican competition against the United States could well be that the United States would start anti-dumping actions and even VERs against Taiwan.

My belief that FTAs will lead to considerable trade diversion (because of modern methods of protection, which are inherently selective and can be captured readily for protectionist purposes) is one that may have been borne out in the EC. It is well known that the EC has used anti-dumping actions and VERs profusely to erect Fortress Europe against the Far East. Cannot much of this be a trade-diverting policy in response to the intensification of internal competition among the member states of the EC?"

Two conclusions follow. (1) If inherently discriminatory regionalism is to flourish, as seems likely, then we need greater discipline for AD actions and VERs: Article VI needs reform and Article XIX needs compliance alongside the elimination of VERs (as the Dunkel draft on the MTN recommends). (2) This also implies that regionalism means, not the redundancy of the GATT, but the need for a stronger GATT. Those who think of the two as alternatives are prisoners of defunct modes of thinking, based on the days when protection was a different beast.

\section{c. Judging Trade-Diversion Case by Case}

While the foregoing analysis embraces a set of policy-framework and incentive-creating reforms to minimise trade diversion, an alternative approach to the problem could be in terms of a case-by-case approach where the approval by the GATT of a proposed CU or FTA would depend on the evaluation of its trade-creating and trade-diverting effects and the requirement that the net anticipated effect be trade-creating.

John McMillan (1991) has argued this in an ingenious paper ${ }^{12}$ which proposes a simple test of admissibility: 'does the bloc result in less trade between member countries and outsider countries?' Based on the welfare economics of customs union theory, this is an aggregative test and has therefore some obvious analytical problems. It is also subject to the problem of computing plausible trade outcomes. It is hard enough to apply it ex post; ex ante, as a test of admissibility, I see little prospect of its being effectively used to exclude any proposed CU or FTA.

\footnotetext{
"Brian Hindley and Patrick Messerlin are investigating this hypothesis for the GATT Secretariat as part of a set of studies to support the 1992 GATT Annual Report on Regionalism and Multilateralism, following the 1991 Annual Report on Trade and the Environment.

12 This paper has also been commissioned by the GATT Secretariat for its 1992 Annual Report, ibid..
} 
Its main merit is its apparent simplicity and its better grounding in economic theory. Therefore, I endorse the advisability of some version of the McMillan test replacing in Article XXIV the current requirement not to raise the average external tariff. But I see it as doing little in practice to avoid trade diversion. For this, we will have to rely on changing the incentive structure, including the use of suitable constraints imposed by stricter discipline on selective and elastic targeting of foreign suppliers. The issue of constraining trade-diversion from proliferating preferential groupings is so important that it may not be a bad idea to combine the proposals made by the present author and McMillan, rather than to treat them as alternatives.

\section{THE DYNAMIC TIME-PATH QUESTION}

The question of the dynamic time-path is particularly difficult: it is almost virgin territory. Perhaps the theoretical approach to customs union theory that appears to be most relevant to this problem is that of Kemp and Wan (1976). In contrast to the Vinerian approach, Kemp and Wan make the external tariff structure endogenously determined for the CU such that it improves the CU members' welfare while maintaining the outsiders' welfare unchanged. This restores the pre-Vinerian intuition that a $\mathrm{CU}$ should be welfare-improving. The problem with the operational significance of the Kemp-Wan argument is that it is really an existence argument, without any structure being put on it within the context of a specific model so that we can develop intuition about what the external tariff structure for such a Kemp-Wan CU would be. ${ }^{13}$ But, that any subset of countries could form an unambiguously (world-) welfare-improving union is definitely established by Kemp and Wan.

This also implies that the time-path to multilateral free trade for all as the optimum optimorum can be made monotonic. ${ }^{14}$ But what it does not say is that the union will necessarily expand and, if so, in a monotonically welfareimproving manner. For that answer, we must turn to the incentive structure that any CU provides to relevant 'groups' for further expansion of the CU.

The incentives in question need not be economic incentives. In fact, it is hard to imagine that the arbitrary groupings of countries that seek FTAs and CUs are dependent on economic arguments as their key determinants. Often, politics seems to drive these choices of partners, as in the case of the EC, and now in the case of FTAs throughout the Americas. This also accounts for the occasional non-regionally-proximate choices of partners in such blocs: e.g. US and Israel,

${ }_{1.3}$ Christopher Bliss (1990) has made a valuable stab at this problem recently.

${ }^{14}$ Such time-paths are clearly not unique. Thus, for instance, any number of such paths could be generated by relaxing the requirement that, at each stage, the nonunion outside countries be left only as well off as before the new expansion of the $\mathrm{CU}$. 
and Pakistan, Iran and Turkey in the early 1960s. But that economic factors contribute to the incentives for such blocs to be formed is not implausible.

Therefore, a meaningful examination of the incentives to form and to expand trade blocs will have to be in the new and growing field of political-economytheoretic analysis. I believe that the models within which we investigate these issues will have to distinguish among at least three kinds of 'agents', which I will detail below with illustrations of the kinds of arguments which we would find relevant:

Governments of member countries. Whether a $\mathrm{CU}$ will expand or not will depend partly on the willingness of the $\mathrm{CU}$ authorities to do so. This will be affected by ideas and ideology. Here I worry that CUs will be under pressure not to expand because one possible reaction to a $\mathrm{CU}$ will be: 'we are already a large market, so what do we really stand to gain by going through the hassle of adding more members?' This is what I call the Our Market Is Large Enough syndrome. I think, as Martin Wolf has often noted, that large countries tend to be more inward-looking for precisely this type of reason.

In addition, the expansion of the $\mathrm{CU}$ to include any specific set of outside countries will imply differential aggregate-welfare effects for current members, implying in turn differential incentives for member countries for and against the expansion. ${ }^{15}$ In this context, a $\mathrm{CU}$ (which generally includes transfers among members) may be more expansionary (à la Kemp-Wan argumentation) than an FTA, though a CU that simultaneously seeks political integration may be less willing to expand.

Interest Groups in members countries. We need also to consider how interest groups, who lobby for or against CU expansion, will behave. Again, since CUs are a balance of trade-creating and protecting forces, it is possible that the protectionists who profit from the diversion of trade away from efficient suppliers abroad to themselves will line up against CU expansion to include those suppliers. The problem then would be the These Are Our Markets syndrome.

It is a sentiment that was beautifully expressed by Signor Agnelli of Fiat: 'The single market must first offer an advantage to European companies. This is a message we must insist on without hesitation. ${ }^{16}$ It is, of course, fine for Signor Agnelli to express such sentiments: after all, Fiat has run for years, not on gas, but on VERs against the Japanese. But should economists also embrace such sentiments?

Interest Groups and Governments of Outside Countries. The third set of 'agents' has to be the outside countries. Here, the example of a CU may lead

${ }^{15}$ This analysis must use the Brecher-Bhagwati (1981) approach to theorising about CUs since it relates to analysing the effects of changes in domestic and external policies and parameters on the distribution of income and welfare among member states.

${ }^{16}$ Quoted by Martin Wolf (1989), 
others to emulate and seek entry. Else, the fear of trade diversion may also induce outsiders to seek entry. If so, this acts as an incentive to expand the CU.

This is clearly an uncharted area that is evidently the most interesting for further analysis. I should cite one empirical study, by Edward Mansfield (1992) which takes trade data for 1850-1965, and estimates an index of 'power distribution' (reflecting, among other things, trade blocs and economic power distribution). When power was centred in hegemons, during periods of British and American hegemony, and when there was 'anarchy', the world economy was relatively liberalised (in the sense that Global Exports/GDP ratio was high); when there were a few middle powers, as could happen with trade blocs, the result was a smaller ratio of trade to GDP.

If Mansfield's analysis is accepted, and if it is considered to be a reasonable approximation to the question whether CUs will have expansionist or protectionist outlooks (mapping perhaps also into their attitudes to $\mathrm{CU}$ expansion or stagnation), then the presumption would be that historical experience suggests that trade blocs will fragment the world economy, not go on to unify it. Of course, history does not always repeat itself. But Mansfield's work certainly suggests caution in place of the gung-ho regionalism that has been urged by the Memorial Drive School.

To conclude, consider the following popular assertions by the regionalists:

- regionalism is quicker;

- regionalism is more efficient; and

- regionalism is more certain.

\section{a. Is Regionalism Quicker?}

The regionalists claim that the GATT is the General Agreement to Talk and Talk, whereas regionalism proceeds quicker. But is this really so?

1. Historically, at least, the First Regionalism failed whereas the GATT oversaw the effective dismantling of prewar tariffs in the OECD countries and the enlargement of disciplines over NTBs at the Tokyo Round and beyond. A little caution, to say the least, is necessary before celebrating regionalism's quickfootedness.

2. For those who believe that regionalism offers a quick route to effective trade liberalisation, Kenneth Dam's analysis quoted above needs renewed attention. There is a world of difference between announcing an FTA or a CU and its implementation; and the comparison is not pleasing if you are in the regional camp.

3. As for speed, even the best example of regionalism, the EC, started almost four decades ago (1957) and is now into 1992. The 'transition' has not therefore been instantaneous any more than negotiated reductions of trade barriers under 
the GATT Rounds. And this too, despite this enormous political support for a united Europe.

4. Take agriculture. The record of regional trade blocs dealing with agricultural trade liberalisation is either nonexistent or dismal. The CAP is not exactly the EC's crowning achievement. In fact, if it were not for multilateralism (i.e the Uruguay Round and the coalition of Cairns Group that crystallised around the MTN), it is difficult to imagine that the process of unravelling the CAP could even have begun.

5. The (actual or potential) exercise of the regional option can also affect the efficacy of the multilateral one. The unwillingness of the EC to start the MTN in 1982 and its largely reactive, rather than leadership, role at the Uruguay Round, are in some degree a reflection of its being less hungry for multilateralism given its internal market size and preoccupations. Then again, is it not evident that, were it not for the EC, the capacity of the French (for whose political predicament one can only have sympathy, much as one deplores its consequence for the willingness to liberalise agriculture) to slow down the reform of the CAP and the liberalisation of world agriculture would have been significantly less?

6. Moreover, if regionalism is available as a realistic option, it will encourage exit rather than the seeking of voice and even the manifestation of loyalty to multilateralism.

- This may happen at the level of the bureaucrats who wind up preferring small-group negotiations among friends (code phrase: 'like-minded people') to the intellectually and politically more demanding business of negotiating with and for the larger community of trading nations.

- Else it may happen that, just as public choice theory à la Olson tells us in regard to the diffusion of consumer losses and concentration of producer gains that favour protectionist outcomes, the proponents of regionalism tend to be better focused and mobilised (they are often regional 'experts' and partisans who ally themselves with the preferred policy options of the countries whose FTA cause they support) whereas the support for multilateralism is often more diffused and less politically effective and therefore takes second place when regionalism is on the political scene.

- Then again, regionalism may appeal to politicians since it translates more easily into votes: the wooing of the Hispanic voters, by urging them to identify with the FTA, was quite evident during the renewal of the fast-track authority last year for the NAFTA negotiations with Mexico.

- The support of business groups for multilateralism may also erode with regional alternatives because of two different reasons: (i) If one can get a deal regionally, where one may have a 'great deal of trade', then one may forget about the multilateral arena. Thus, if Canada could get the US to agree to a fairer operation of the unfair trade mechanisms, (a matter on 
which many Canadians today feel they were mistaken, with Prime Minister Mulroney and Mr. Riesman talking about Americans being 'thugs' or like 'third world dictators'), ${ }^{17}$ why bother to fight the battles at the Uruguay Round where the powerful American manufacturing lobbies, zeroing in with the EC against the Far East, seek instead to weaken the GATT rules? (ii) Again, one may get better protectionist, trade-diversionary deals for oneself in a preferential arrangement than in the nondiscriminatory world of the GATT: e.g. Mexico's textile interests should benefit in the NAFTA relative to Caribbean and other external competitors in the US market, weakening Mexican incentive to push for reform in the MFA forthwith.

7. Finally, it is true that the free rider problem looks difficult as the number of GATT members increases steadily. Yet, recent theoretical work on GATT-style trade negotiations (Ludema, 1990) suggests that the free rider problem may not be an effective barrier to freeing trade. Moreover, as Finger (1982) has pointed out, and as experience of inadequate GSP concessions underlines, developing countries have not been able to free ride as much as their exemption from reciprocity under $S \& D$ treatment would imply: the trade concessions on commodities of interest to them have not gone as far as the concessions on commodities of interest to other GATT members without such an exemption. (Unconditional) MFN does not work in practice as well as it should from the free-riders' perspective!

\section{b. Is Regionalism More Efficient?}

Occasionally, one finds the regionalists arguing that regionalism is also more efficient: it produces better results. A typical argument is that, as part of the NAFTA negotiations, Mexico has accepted virtually all the US demands on intellectual property (IP) protection. A funny story, told in developing country circles, serves to probe this assertion critically:

Ambassador Carla Hills was on a tour of South America, extolling the virtues of Mexico's 'capitulation.' At a dinner in her honour in Caracas, she apparently claimed: 'Mexico now has world-class IP legislation.' At this point, President Carlos Peretz supposedly turned to his left and remarked: 'But Mexico does not have a world-class parliament.'

The true moral of the story, however, is that, as part of the bilateral quid pro quos in an FTA or CU, weak states may agree to specific demands of strong states, ${ }^{18}$ in ways that are not exactly optimal from the viewpoint of the economic

\footnotetext{
17 Those who think that much of Japan-bashing is not prejudiced may want to think about the differential and exaggerated reaction in the US to the bumbling and far more innocuous remarks of Prime Minister Miyazawa and Speaker Sakarauchi.

I" In Mexico's case, President Salinas' political stake in getting an FTA with the US is vastly disproportionate to President Bush's.
} 
efficiency of the world trading system. In turn, however, these concessions can distort the outcome of the multilateral negotiations.

This may well have happened with TRIPs and TRIMs at the Uruguay Round. ${ }^{19}$ As is now widely conceded among economists, the case for TRIPs for instance is not similar to the case for free trade: there is no presumption of mutual gain, world welfare itself may be reduced by any or more IP protection, and there is little empirical support for the view that 'inadequate' IP protection impedes the creation of new technical knowledge significantly. ${ }^{20}$ Yet, the use of US muscle, unilaterally through Special 301 actions, and the playing of the regional card through the NAFTA carrot for Mexico, have put TRIPs squarely and effectively into the MTN.

Again, a distorting impact on the multilateral trade rules from NAFTA negotiations can be feared from the fact that, as a price for the latter to be accepted by the Congress during the delicate renewal of fast-track authority, the US Administration had to accept demands for harmonisation in environment and labour standards by Mexico towards US standards. This effectively linked in political circles the case for Free Trade with the demands for 'level playing fields' or Fair Trade (extremely widely interpreted), ${ }^{21}$ legitimating these demands and weakening the ability of economists and of governments negotiating at the GATT (multilaterally for arm's length Free Trade) to resist this illegitimate constraint on freeing trade.22

\section{c. Is Regionalism More Certain?}

Much has been made, in the Mexican context, of the argument that the FTA will make trade liberalisation irreversible. But something needs to be added here:

- GATT also creates commitments: tariffs are bound. (This does not apply to concessions made under conditionality, of course, by IMF or IBRD.) Mexico is a member, if recent, of the GATT.

\footnotetext{
${ }^{19}$ TRIPs are trade-related intellectual property provisions and TRIMs are trade-related investment measures. The weakness of the case for their inclusion in the GATT, at least in the forms canvassed by many lobbies, is discussed in Bhagwati (1991a).

${ }^{20}$ It is not surprising therefore that the spokesmen for TRIPs have shifted from utilitarian methods of argumentation to 'rights': they talk now of 'theft' and 'piracy'.

21 That the environmental and labour standards negotiations in NAFTA will be "parallel" rather than 'integrated' is of no consequence, any more than running the services negotiations parallel to other negotiations at the Uruguay Round has been.

${ }^{22}$ The danger posed by the proliferating demands for 'level playing fields' or Fair Trade, chiefly in the United States but elsewhere too, is extremely serious. It is analysed, and the theoretical questions raised by it are noted, in Bhagwati (1992b). The environment issue, in particular, has been discussed in this context in the 1991 GATT Annual Report, ibid.
} 
- Recall Dam (quoted above): Article XXIV is so full of holes in its discipline that almost anything goes. Reductions of trade barriers can be slowed down, as 'circumstances' require, other bindings can be torn up by mutual consent (an easier task when there are only a few members in the bloc but more difficult under the GATT), etc.

- Recall too that regional agreements have failed (LAFTA) and stagnated (ASEAN) as well. The current mood in Canada over NAFTA is sour and the MTN looks better in consequence. ${ }^{23}$ The sense however, that the US has let Canada down and failed to live by the spirit of the FTA agreements will probably not endure. But who knows?

\section{CONCLUDING REMARKS}

The question of regionalism is thus both a difficult and delicate one. Only time will tell whether the revival of regionalism since the 1980 s will have been a sanguine and benign development or a malign force that will serve to undermine the widely-shared objective of multilateral free trade for all.

My judgement is that the revival of regionalism is unfortunate. But, given its political appeal and its likely spread, I believe that it is important to contain and shape it in ways sketched here so that it becomes maximally useful and minimally damaging, and consonant with the objectives of arriving at multilateral free trade for all.

\section{REFERENCES}

Berglas, E. (1979) 'Preferential Trading Theory: The n Commodity Case,' Journal of Political Economy, 87, 315-331.

Bhagwati, J. N. (1968), 'Trade Liberalization Among LDCs, Trade Theory and GATT Rules,' in J. N. Wolfe (ed.), Value, Capital, and Growth: Papers in Honour of Sir John Hicks (Edinburgh: University of Edinburgh Press).

Bhagwati, J. N. (1991a), The World Trading System at Risk (Princeton: Princeton University Press).

Bhagwati, J. N. (1991b), 'Revealing Talk on 'Trade,' The American Enterprise, 2, 72-78.

Bhagwati, J. N. and T. N. Srinivasan (1983), Lectures on International Trade (Cambridge: MIT Press).

Bliss, C. (1990), London: CEPR, Mimeograph.

Brecher, R. and J. N. Bhagwati (1981), 'Foreign Ownership and the Theory of Trade and Welfare,' Journal of Political Economy, 89, 497-512.

Cooper, C. A. and B. F. Massell (1965a), 'A New Look at Customs Union Theory,' The Economic Journal, 75, 742-47.

\footnotetext{
23. John Whalley's (1992) splendid paper for this Conference on the US-Canada FTA strongly supports the sceptical views that I have advanced of the Second Regionalism's prospect and wisdom.
} 
Cooper, C. A. and B. F. Massell (1965b), 'Toward a General Theory of Customs Unions for Developing Countries,' Journal of Political Economy, 73, 461-76.

Corden, W. M. (1976), 'Customs Union Theory and the Nonuniformity of Tariffs,' Journal of International Economics, 6, 99-107.

Dam, K. (1970), The GATT: Law and International Economic Organization (Chicago: University of Chicago Press).

Dornbusch, R. et. al. (1989), Meeting World Challenges: United States Manufacturing in the 1990s (Pamphlet issued by Eastman Kodak Company, Rochester, NY).

The Economist (1991), Economics Focus Column (July).

Finger, J. M. (1989), 'Picturing America's Future: Kodak's Solution of American Trade Exposure,' The World Economy, 12, 377-80.

Gowa, J. and E. Mansfield (1991), 'Allies, Adversaries, and International Trade,' Paper presented at the American Political Science Association Meetings, Washington, DC, mimeo.

Grandmont, J. M. and D. McFadden (1972), 'A Technical Note on Classical Gains from Trade,' Journal of International Economics, 109-125.

Johnson, H. G. (1958a), 'The Gains from Free Trade with Europe: An Estimate,' Manchester School of Economic and Social Studies, 36, 247-65.

Johnson, H. G. (1958b), 'The Economic Gains from Free Trade with Europe,' Three Banks Review:

Johnson, H. G. (1965), 'An Economic Theory of Protectionism, Tariff Bargaining, and the Formation of Customs Unions', Journal of Political Economy, 73, 256-83.

Johnson, H. G. (1967), Economic Policies Toward Less Developed Countries (Washington: Brookings Institution).

Kemp, M. C. (1972), 'The Gains from International Trade,' Economic Journal, 72, 803-819.

Kemp, M. C. and H. Wan (1976), 'An Elementary Proposition Concerning the Formation of Customs Unions,' Journal of International Economics, 6, 95-98.

Lipsey, R. G. (1957), 'The Theory of Customs Unions: Trade Diversion and Welfare,' Economica.

Lipsey, R. G. (1958), The Theory of Customs Unions: A General Equilibrium Analysis, Ph.D. Thesis, University of London.

Lipsey, R. G. (1960). 'The Theory of Customs Unions: A General Survey,' The Economic Journal, 70, 496-513.

Lipsey, R. G. and K. J. Lancaster (1956-57), 'The General Theory of Second Best,' Review' of Economic Studies, 24, 33-49.

Ludema, R. (1991), 'International Trade Bargaining and the Most Favoured Nation Clause,' Economics \& Politics, 3, 1-41.

Mansfield, E. (1992), 'The Concentration of Capabilities and International Trade,' International Organization, forthcoming.

McMillan, J. (1991), 'Do Trade Blocs Foster Open Trade?' University of California at San Diego; mimeo.

Meade, J. E. (1956), The Theory of Customs Unions (New York: North Holland).

Samuelson, P. A. (1939), 'The Gains from International Trade,' Canadian Journal of Economics and Political Science, 5, 195-205.

Saxonhouse, G. (1992), 'Trading Blocs, Pacific Trade, and the Pricing Strategy of East Asian Firms', Paper presented to the World Bank Conference on New' Dimension in Regionalism (April 2-3).

Viner, J. (1950), The Customs Unions Issue, Carnegie Endowment for International Peace.

Whalley, J. (1992), 'Regional Trade Arrangements in North America: CUSTA and NAFTA', Paper presented to the World Bank Conference on New' Dimensions in Regional Integration (April 2-3).

Wolf, M. (1989), 'European Community 1992: the Lure of the Chasse Gardee'. The World Economy, 12, 373-376. 
